\title{
Surviving Starvation: Essential Role of the Ghrelin-Growth Hormone Axis
}

\author{
J.L. Goldstein, T.-j. Zhao, R.L. Li, D.P. Sherbet, G. Liang, and M.S. Brown \\ Department of Molecular Genetics, University of Texas Southwestern Medical Center, \\ Dallas, Texas 75390-9046 \\ Correspondence: joe.goldstein@utsouthwestern.edu or mike.brown@utsouthwestern.edu
}

\begin{abstract}
After brief starvation, vertebrates maintain blood glucose by releasing fatty acids from adipose tissue. The fatty acids provide energy for gluconeogenesis in liver and are taken up by muscle, sparing glucose. After prolonged starvation, fat stores are depleted, yet blood glucose can be maintained at levels sufficient to preserve life. Using a new mouse model, we demonstrate that survival after prolonged starvation requires ghrelin, an octanoylated peptide hormone that stimulates growth hormone $(\mathrm{GH})$ secretion. We studied wild-type mice and mice lacking ghrelin as a result of knockout of GOAT, the enzyme that attaches octanoate to ghrelin. Mice were fed $40 \%$ of their normal intake for $7 \mathrm{~d}$. Fat stores in both lines of mice became depleted after 4 d. On day 7, mice were fasted for $23 \mathrm{~h}$. In wild-type mice, ghrelin and GH rose massively, and blood sugar was maintained at $\sim 60 \mathrm{mg} / \mathrm{dL}$. In Goat $^{-1-}$ mice, ghrelin was undetectable and GH failed to rise appropriately. Blood sugar declined to $\sim 20 \mathrm{mg} / \mathrm{dL}$, and the animals were moribund. Infusion of ghrelin or GH prevented hypoglycemia. Our results support the following sequence: (1) Starvation lowers blood glucose; (2) glucose-sensing neurons respond by activating sympathetic neurons; (3) norepinephrine, released in the stomach, stimulates ghrelin secretion; (4) ghrelin releases GH, which maintains blood glucose. Thus, ghrelin lies at the center of a hormonal response that permits mice to survive an acute fast superimposed on chronic starvation.
\end{abstract}

Starvation is a constant threat to all living organisms. Survival depends upon mechanisms that preserve blood glucose, an essential energy source for several organs. In fasted vertebrates, blood glucose is preserved by the release of fatty acids from adipose tissue stores, release of lactate and alanine from muscle, and the use of these metabolites to provide energy and substrate for glucose production in the liver (Cahill 2006).

Fatty acids are of special importance in preserving blood glucose. In addition to providing energy and NADH required for hepatic gluconeogenesis, plasma fatty acids are used directly for oxidation in muscle, thereby sparing glucose. Partial oxidation of fatty acids in liver leads to secretion of ketone bodies that can be used for energy in the nervous system (Cahill 2006). These wellknown mechanisms can maintain the survival of animals for brief periods of nutrient deprivation, but what happens when starvation is prolonged? After prolonged famine, adipose triglyceride stores are exhausted and fatty acids are no longer released to spare glucose or to provide energy for gluconeogenesis. How can an animal maintain blood glucose levels high enough to support life when fatty acids are no longer available? Insights into these extreme defense mechanisms have emerged from studies of a recently discovered hormone called ghrelin.

\section{GHRELIN, AN OCTANOYLATED PEPTIDE HORMONE}

Ever since its discovery by Kojima, Kangawa, and colleagues in 1999 (Kojima et al. 1999), the physiological role of ghrelin, an octanoylated peptide hormone, has been obscure (Fig. 1). Ghrelin is produced primarily by rare neuroendocrine cells in the stomach, and it acts in the arcuate nucleus of the hypothalamus and in somatotrophs in the pituitary to release growth hormone (Fig. 2). In humans and rodents, plasma ghrelin concentrations rise dramatically before meals and decline precipitously after food ingestion (Cummings et al. 2001; Nass et al. 2008). Administration of excess ghrelin increases food intake (Tschop et al. 2000; Kamegai et al. 2001; Wren et al. 2001). Therefore, ghrelin was suspected to function as a hunger signal, stimulating appetite. However, only modest and inconsistent decreases in appetite were observed in mice lacking ghrelin or its receptor as a result of gene knockouts (Sun et al. 2003; Wortley et al. 2004; Zigman et al. 2005). Moreover, the knockout mice showed no impairment of body growth, indicating that growth hormone was normal. Despite the lack of consequences of ghrelin loss, the hormone is conserved in all vertebrates (Kojima and Kangawa 2005), implying that it must have an essential function, the nature of which is not apparent.

Our interest in ghrelin was stimulated by the finding of Kojima and Kangawa that the 28 -amino acid peptide is covalently modified with octanoate, an eight-carbon fatty acid, attached to serine-3 in an $O$-acyl linkage. Like ghrelin itself, the octanoate modification is conserved throughout the vertebrate lineage (Kojima and Kangawa 2005). Moreover, the octanoate moiety is essential for the function of ghrelin in releasing growth hormone from pituitary cells. Ghrelin is the only protein 
A

Ghrelin

- Discovered by Kojima and Kangawa - 1999

- Peptide hormone - 28 amino acids

- Produced in stomach ( $1 \%$ of cells) as preproghrelin

- Modified by O-acylation with octanoate (8 carbon fatty acid)

- Octanoylation is essential for biologic activity

- Two forms in blood: Ghrelin \& Desacyl-Ghrelin

- Ghrelin acts on GH Secretagogue Receptor (GHS-R) in arcuate hypothalmus \& pituitary gland

B

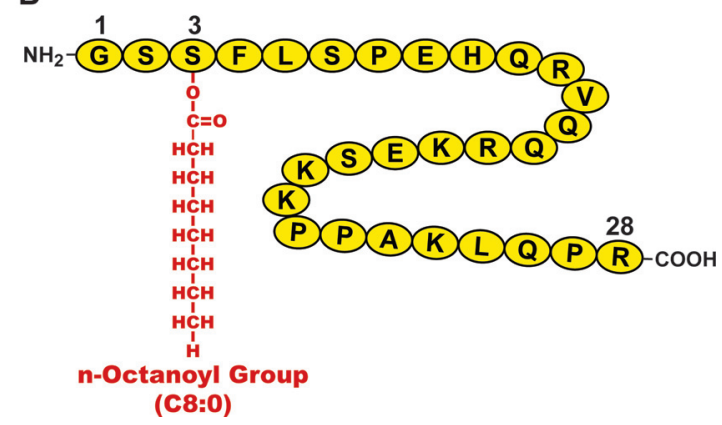

Figure 1. Ghrelin, an octanoylated peptide. (A) Background. (B) Amino acid sequence of human ghrelin, showing the site of $O$-linked acylation with octanoate at serine-3.

known to be modified by octanoate, implying the existence of an enzyme specialized to make this addition.

\section{IDENTIFICATION OF GOAT, THE ENZYME THAT OCTANOYLATES GHRELIN}

We reasoned that the octanoylating enzyme would be a member of a recently recognized family of enzymes termed MBOATs (membrane bound $O$-acyltransferases) (Hofmann 2000). Members of this family were known to attach long chain fatty acids to the hydroxyl group of cholesterol as well as to the hydroxyl of a serine residue in Wingless (Wnt), a secreted protein. Our analysis of the human and mouse genomes revealed 16 putative MBOATs, of which five had no assigned function. Jing Yang, a graduate student in our laboratory, used stomach RNA as a source to prepare cDNAs encoding all 16 MBOATs and introduced them by transfection into INS- 1 cells, a line of rat endocrine cells that is known to cleave prohormones to their mature forms. When forced to express proghrelin by transfection, INS-1 cells cleaved the 94-amino acid proghrelin to the 28-amino mature form, but the ghrelin did not contain octanoate (Yang et al. 2008a). One of the 16 MBOATs, MBOAT-4, was able to confer the ability to attach octanoate to des-acyl ghrelin. We named this enzyme GOAT, which stands for ghrelin $O$-acyltransferase. Fractionation of stomach cells by cell sorting revealed that the GOAT mRNA was enriched in the same rare cell population that expressed immunoreactive ghrelin (Sakata et al. 2009). Scientists at Eli Lilly and Company also identified
GOAT as MBOAT-4 and reported their findings soon after ours (Gutierrez et al. 2008).

Ghrelin represents the $\mathrm{NH}_{2}$-terminal 28-amino acids of proghrelin, which is produced from preproghrelin by cleavage of the signal peptide. We set up an in vitro assay to measure the ability of recombinant GOAT to transfer octanoate from octanoyl-CoA to recombinant proghrelin (Yang et al. 2008b). Mutational analysis revealed that the enzyme recognized the five $\mathrm{NH}_{2}$-terminal residues of proghrelin. Transfer of octanoyl to proghrelin could be competitively inhibited by pentapeptides corresponding to this sequence, raising the possibility that pharmacologic inhibition could be achieved by peptidomimetic compounds.

\section{FUNCTIONAL ANALYSIS OF Goat $^{-/-}$ KNOCKOUT MICE}

To confirm the function of GOAT, we disrupted the gene in the germline of mice by homologous recombination. In the discussion below, we use the term ghrelin to denote octanoylated ghrelin and des-acyl ghrelin to indicate ghrelin lacking the octanoate residue. Goat ${ }^{-/-}$ homozygotes failed to produce any ghrelin, although they produced normal to increased amounts of des-acyl ghrelin (Zhao et al. 2010a). Like the ghrelin and ghrelin receptor knockout mice, the Goat $^{-1}{ }^{-}$mice grew normally and appeared entirely normal when fed normal chow. Moreover, they gained the same amount of weight as wild-type (WT) littermates when placed on a high-fat diet. Finally, Goat ${ }^{-/-}$mice showed the same voracious appetite when refed after a short-term fast. All of these findings indicated that ghrelin is not essential for normal hunger responses in mice.

\section{Protocol for Chronic Calorie Restriction}

In searching for an essential function of ghrelin, we devised a protocol to subject wild-type and Goat $^{-/-}$ mice to chronic calorie deprivation (intake of $40 \%$ of

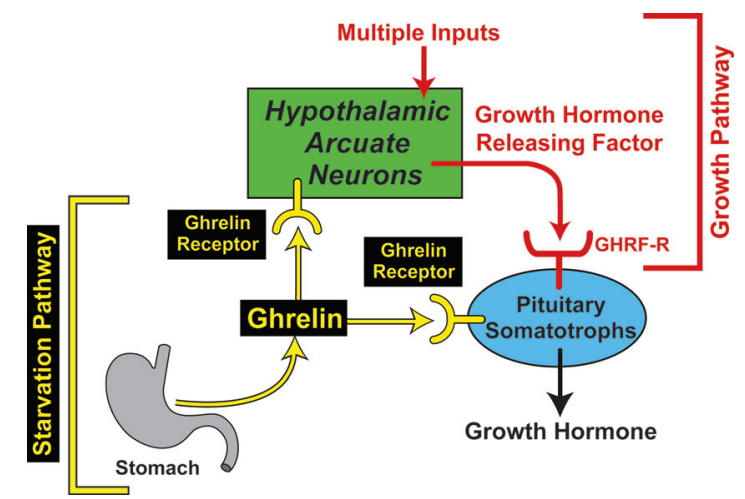

Figure 2. Model illustrating two different pathways for release of growth hormone $(\mathrm{GH})$. The ghrelin-mediated pathway (denoted in yellow) comes into play during prolonged starvation and is not essential for body growth. This pathway is distinct from the canonical GH releasing factor pathway (denoted in red), which is essential for body growth and plays a minor role during prolonged starvation. 


\section{$60 \%$ Calorie Restriction}

- Each mouse fed $40 \%$ of its daily food intake for 7-9 days

- Food supplied at $6 \mathrm{pm}$ each day and eaten within $1 \mathrm{hr}$

- Blood glucose measured each day at 5:30 pm (22.5 hr after eating and $30 \mathrm{~min}$ before next feeding)

Figure 3. Protocol for studies of prolonged starvation in mice. Additional details are described in Zhao et al. (2010a).

normal calories), mimicking famine (see Fig. 3). The mice were fed each day at 6 p.m. After one day of this regimen, the Goat $^{-/-}$mice and wild-type mice became ravenously hungry and consumed their entire allotment of food within $1 \mathrm{~h}$. Within $4 \mathrm{~d}$, wild-type and Goat $^{-/-}$mice each lost about $30 \%$ of body weight (Fig. 4A) and 75\% of their body fat (Fig. 4B). We measured blood glucose each day at 5:30 p.m., $22.5 \mathrm{~h}$ after the last meal had been consumed. On the first day, blood glucose declined equally in wild-type and Goat ${ }^{-/-}$mice, reaching about $60 \mathrm{mg} / \mathrm{dL}$. In wild-type mice the blood glucose stabilized at this level for the next $6 \mathrm{~d}$. In contrast, blood glucose in the Goat $^{-/-}$mice declined progressively, reaching a nadir of less than $20 \mathrm{mg} / \mathrm{dL}$ on day 7 , at which time the moribund mice were killed (Zhao et al. 2010a).

\section{Acute Starvation following Chronic Calorie Restriction Leads to Hypoglycemia in Goat $^{-/-}$Mice}

Figure 5 shows that the plasma levels of ghrelin and des-acyl ghrelin rose progressively over the $7 \mathrm{~d}$ of calorie restriction in wild-type mice when measured at 5:30 p.m. (Fig. 5B and C, respectively). In Goat ${ }^{-/-}$mice, there was no detectable ghrelin (Fig. 5B), but des-acyl ghrelin rose to the same extent as it did in wild-type mice (Fig. 5C). In wild-type mice, plasma growth hormone rose in proportion to the rise in ghrelin. The rise in Goat $^{-/-}$mice was markedly reduced (Fig. 5D).
A study of diurnal variation revealed that even after $7 \mathrm{~d}$ of calorie restriction, the Goat $^{-/-}$mice had the same blood sugar level as the wild-type mice at 9 a.m., $15 \mathrm{~h}$ after their last meal. In wild-type mice the blood sugar remained relatively constant throughout the next $8 \mathrm{~h}$, but it fell progressively in the Goat $^{-/-}$mice until it reached its nadir just before the next meal. Thus, hypoglycemia in Goat $^{-1-}$ mice requires two conditions: (1) chronic calorie restriction, leading to a near-complete disappearance of adipose tissue triglycerides; and (2) acute fasting over a 23 -h period. The lack of adipose tissue in these mice is reflected in a low plasma level of free fatty acids and ketone bodies, despite the 23 -h fast (Zhao et al. 2010a). Whereas wild-type mice can tolerate these conditions and still maintain sufficient blood sugar for survival, Goat ${ }^{-/-}$mice cannot compensate, and so they succumb.

In unpublished data, we repeated these caloriedeprivation experiments in mice lacking ghrelin, owing to the elimination of the ghrelin gene by homologous recombination. These mice showed the identical susceptibility to chronic calorie restriction as did the $\mathrm{Goat}^{-/-}$ mice. Whereas the Goat $^{-/-}$mice produced normal amounts of des-acyl ghrelin, the ghrelin knockout mice lacked both forms of the peptide. These data rule out a major contribution of des-acyl ghrelin to glucose production in calorie-restricted mice.

\section{Infusion of Ghrelin or Growth Hormone Prevents Hypoglycemia in Goat $^{-/-}$Mice}

In the Goat $^{-/-}$mice, infusion of ghrelin via an osmotic minipump prevented the hypoglycemia induced by chronic calorie restriction (Fig. 6B). Similar prevention was obtained when growth hormone was infused (Fig. 6D). Both infusions were initiated $3 \mathrm{~d}$ before the start of the calorie restriction and maintained throughout.

Aside from their relative growth hormone deficiency, the Goat $^{-/-}$mice appeared to make a normal hormonal response to hypoglycemia. When measured at 5:30 p.m., the calorie-restricted wild-type and Goat ${ }^{-/-}$mice had
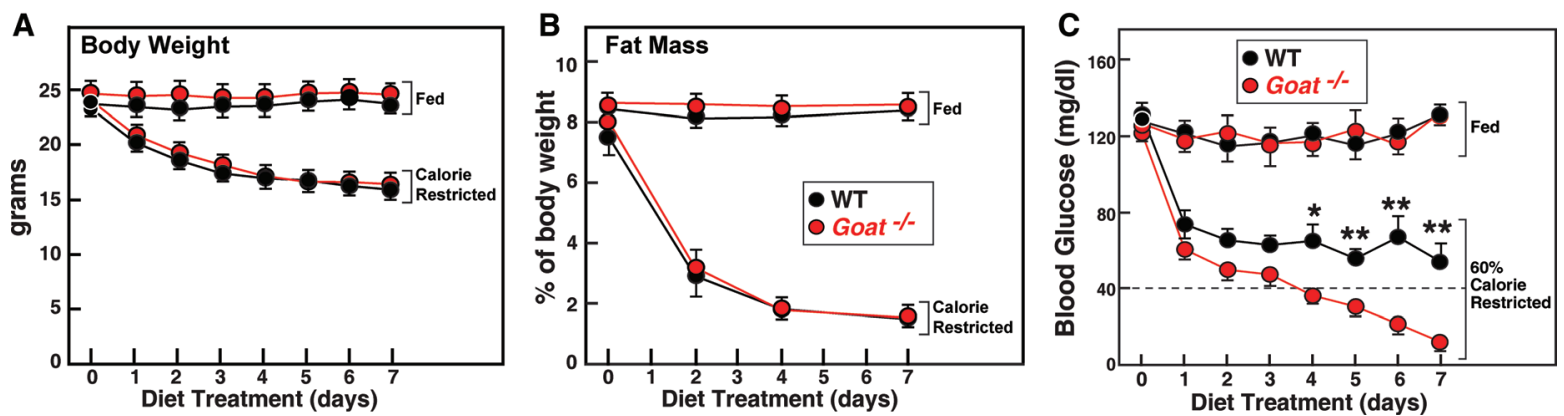

Figure 4. Body weight $(A)$, fat mass $(B)$, and blood glucose $(C)$ in wild-type and Goat $^{-/}$- mice subjected to $60 \%$ calorie restriction. Male littermates ( $8 \mathrm{wk}$ old) were housed in individual cages and fed $a d$ lib with a chow diet or subjected to $60 \%$ calorie restriction as described in Figure 3. Body weight $(A)$ was measured daily at 5:30 p.m., and total fat mass $(B)$ was measured by NMR every 2 or $3 \mathrm{~d}$ at 5 p.m. Blood glucose $(C)$ was measured daily with a Bayer Glucometer at 5:30 p.m. (30 min before feeding). Each value represents mean \pm S.E.M. of data from six mice. In $C$, asterisks denote the level of statistical significance (Student's $t$ - test) between the wild-type and Goat ${ }^{-1-}$ mice. ${ }^{*} p<0.05,{ }^{* *} p<0.01,{ }^{* * *} p<0.001$. (Reprinted from Zhao et al. 2010a.) 


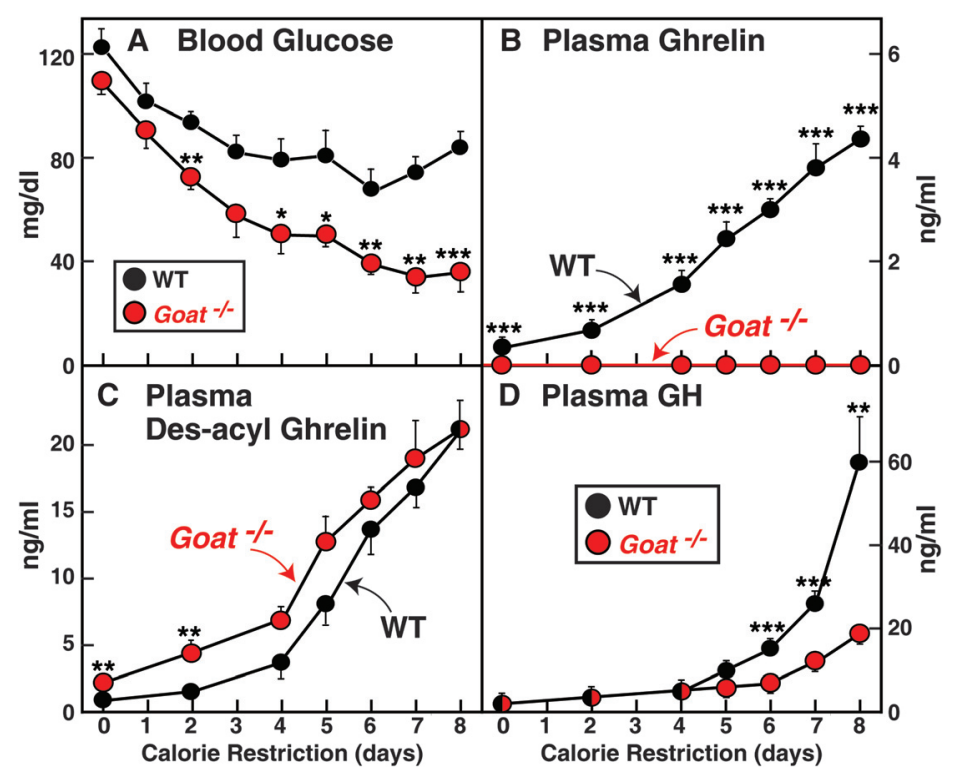

Figure 5. Changes in blood glucose and growth hormone in wild-type and $\mathrm{Goat}^{-/-}$mice subjected to calorie restriction. Male wildtype and Goat $^{-9-}$ littermates ( 8 wk old) were subjected to $60 \%$ calorie restriction. Concentrations of blood glucose $(A)$, plasma ghrelin $(B)$, plasma des-acyl ghrelin $(C)$, and plasma growth hormone $(D)$ were measured at 5:30 p.m. (30 min before feeding) on the indicated day. Each value represents the mean \pm S.E.M. of data from five mice. Asterisks denote the level of statistical significance (Student's $t$-test) between wild-type and Goat ${ }^{-}{ }^{I-}$ mice. ${ }^{*} p<0.05,{ }^{* *} p<0.01,{ }^{* * *} p<0.001$. (Reprinted from Zhao et al. 2010a.) WT, wildtype. $\mathrm{GH}$, growth hormone.
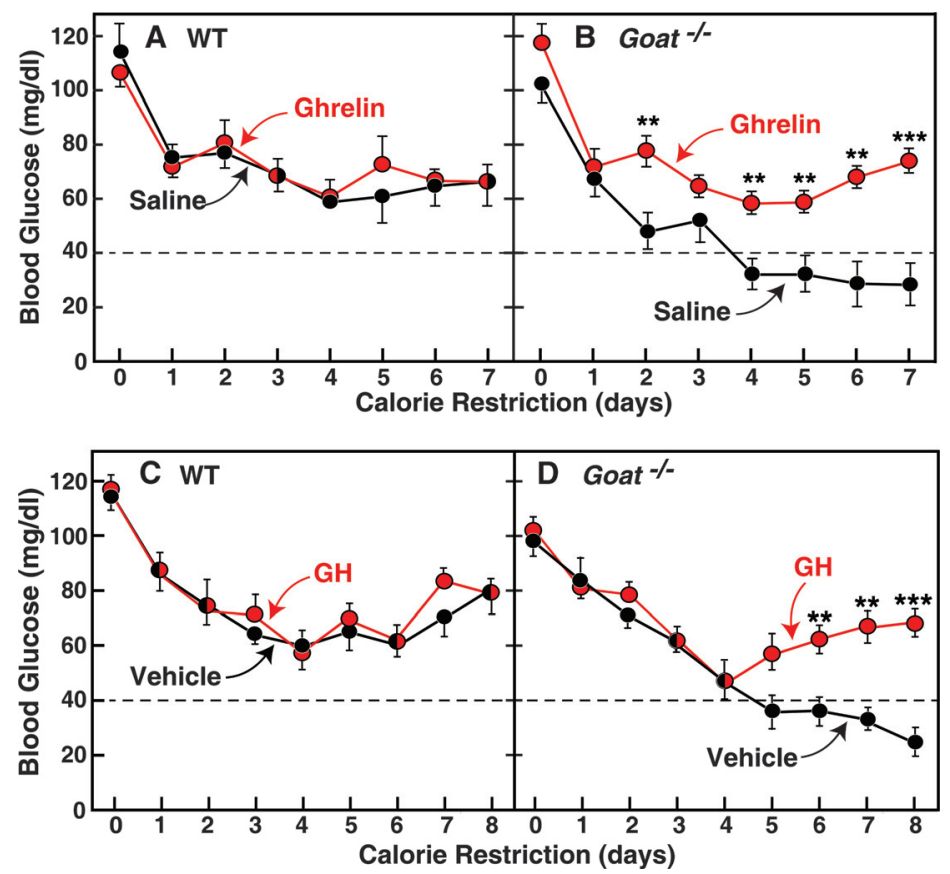

Figure 6. Infusion of ghrelin $(A, B)$ or growth hormone $(C, D)$ prevents hypoglycemia in calorie-restricted Goat ${ }^{-/-}$mice. Alzet osmotic pumps (delivery rate of $0.25 \mu \mathrm{L} / \mathrm{h}$ ) were filled with either saline or saline containing $5 \mathrm{mg} / \mathrm{mL}$ ghrelin $(A, B)$, or with vehicle $(\bullet)$ or vehicle containing $2.5 \mathrm{mg} / \mathrm{mL}$ growth hormone $(C, D)$. The pumps were implanted subcutaneously in the interscapular regions of 8 -wk-old male littermate wild-type and Goat ${ }^{-/-}$mice. Three days after initiation of the infusion, both groups of mice were subjected to $60 \%$ calorie restriction that was continued for $7(A, B)$ or $8(C, D)$ d. Blood glucose levels were measured daily at 5:30 p.m. (30 min before feeding). Each value represents the mean \pm S.E.M. of data from six $(A, B)$ or five $(C, D)$ mice. Asterisks denote the level of statistical significance (Student's $t$-test) between Goat ${ }^{-1}$ - mice infused with saline or ghrelin, or vehicle or growth hormone. ${ }^{*} p<$ $0.05,{ }^{* *} p<0.01,{ }^{* * *} p<0.001$. (Reprinted from Zhao et al. 2010a.) WT, wild-type. GH, growth hormone. 
undetectable levels of plasma insulin and elevated levels of glucagon that were equal in the two lines of mice. Plasma corticosterone levels were also similar in the two strains. The glucagon elevation was manifested by a marked increase in hepatic mRNAs encoding the gluconeogenic enzymes, phosphoenolpyruvate carboxykinase and glucose-6-phosphatase. These increases were equal in the wild-type and Goat $^{-/-}$mice (Zhao et al. 2010a; T-j Zhao, JL Goldstein, and MS Brown, unpubl. data).

\section{HOW DOES GROWTH HORMONE DEFICIENCY PRODUCE HYPOGLYCEMIA IN CALORIE-RESTRICTED Goat $^{-/-}$MICE?}

Considered together, the data so far indicate that Goat $^{-/-}$mice become hypoglycemic because of a deficiency of growth hormone. Hypoglycemia might be caused by accelerated glucose removal, by limited glucose production or a combination of the two. Whether glucose uptake is normal or accelerated, it is clear that the liver is not able to increase gluconeogenesis sufficiently to meet the demand. We have not yet measured the activities of the relevant hepatic enzymes, but the marked elevations in their mRNAs suggest that the amounts of these enzymes are likely to be elevated. Rather, the problem in the Goat $^{-/-}$mice is likely to be caused by an insufficiency of substrates and/or the energy needed to convert these substrates to glucose. The major substrates for gluconeogenesis are lactate and alanine, and the major energy comes from fatty acid oxidation (Cahill 2006). Somehow, growth hormone must maintain hepatic gluconeogenesis even when fatty acids are absent. Our current efforts are focused on testing these hypotheses and elucidating the mechanism.

\section{HOW DO GASTRIC GHRELIN-SECRETING CELLS RESPOND TO HYPOGLYCEMIA?}

Other questions in this field relate to the mechanism by which the endocrine cells in the stomach respond to hypoglycemia by secreting ghrelin, which in turn stimulates growth hormone secretion. Earlier indirect evidence suggested that the sympathetic nervous system might stimulate ghrelin secretion (Mundinger et al. 2006; Hosoda and Kangawa 2008), but the hypothesis could not be tested directly, owing to the paucity of ghrelin-secreting cells in the stomach. To circumvent this problem, we and our colleagues created lines of ghrelin-secreting tumor cells that could be maintained in tissue culture (Zhao et al. 2010b). For this purpose, we created a BAC transgene encoding oncogenic SV40 T-antigen driven by the promoter of the ghrelin gene. By 20-24 weeks of age, the transgenic mice developed ghrelin-secreting tumors in the stomach (100\% of mice) and pancreas (50\%). Tumors were removed, and the cells were dissociated and placed in tissue culture, where they proliferated and secreted ghrelin. Two stable and clonally derived ghrelinoma cell lines were isolated, PG-1 cells from pancreatic ghrelinomas and SG-1 cells from stomach ghrelinomas (Zhao et al. 2010b).

We treated the cultured ghrelinoma cells with a variety of peptide hormones and then measured ghrelin secretion (Fig. 7A). Of the 10 peptide hormones tested, none stimulated ghrelin secretion in either PG-1 or SG-1 cells. In contrast, norepinephrine stimulated ghrelin secretion two- to threefold at a half-maximal concentration of $0.1 \mu \mathrm{M}$ in both cell lines (Zhao et al. 2010b). Forskolin mimicked the norepinephrine effect, indicating that the neurotransmitter acted by activating adenylyl cyclase (Fig. 7B). Epinephrine also stimulated ghrelin secretion
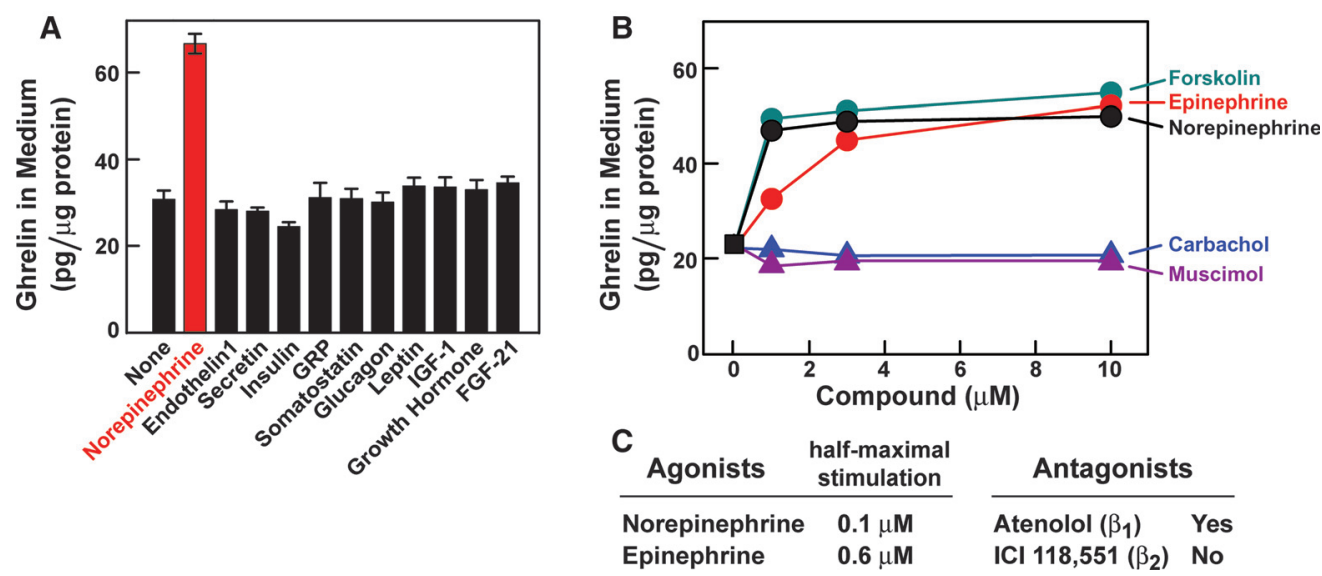

Figure 7. Effect of various receptor agonists on stimulation of ghrelin secretion in ghrelinoma cells. $(A)$ On day 0 , PG-1 ghrelinoma cells were set up in DMEM/F-12 medium with $10 \%$ FBS. On day 2, octanoate was added to a final concentration of $50 \mu \mathrm{M}$. On day 3 , cells were centrifuged, resuspended in serum-free medium with $50 \mu \mathrm{M}$ octanoate, aliquoted into 24 -well plates $\left(5 \times 10^{4}\right.$ cells $/$ well $)$, and treated with $100 \mathrm{nM}$ of the indicated peptide hormone or $10 \mu \mathrm{M}$ norepinephrine. After incubation at $37^{\circ} \mathrm{C}$ for $6 \mathrm{~h}$, the medium from each well was harvested for measurement of ghrelin as described (Zhao et al. 2010b). (B) Dose-dependent stimulation of ghrelin secretion by adrenergic, but not by a cholinergic or a GABA agonist, in PG-1 cells. Cells were set up for experiments as in $A$. On day 3 , cells were treated with varying concentrations of the indicated compound. After incubation at $37^{\circ} \mathrm{C}$ for $6 \mathrm{~h}$, the medium from each well was harvested for measurement of ghrelin. Each value is the average of duplicate incubations. $(C)$ Results from detailed concentration curves. (Reprinted from Zhao et al. 2010b.) 
two- to threefold, but the concentration required for halfmaximal stimulation was sixfold higher than that for norepinephrine (Fig. 7C). Dopamine, the catecholamine precursor, had minimal stimulatory effect $(<30 \%)$ at concentrations up to $100 \mu \mathrm{M}$ (T-j Zhao, JL Goldstein, and MS Brown, unpubl. data). The muscarinic agonist carbachol and the GABA agonist muscimol failed to stimulate ghrelin secretion (Fig. 7B).

The above characteristics are consistent with stimulation through the $\beta_{1}$ adrenergic receptor. Consistent with this hypothesis, the effect of norepinephrine was blocked by atenolol, a specific antagonist of the $\beta_{1}$ adrenergic receptor, but not by ICI 118,551, a $\beta_{2}$ receptor antagonist (Fig. 7C). Moreover, we found that the mRNA encoding the $\beta_{1}$ receptor was enriched $>50$-fold both in the cultured ghrelinoma cells and in ghrelin-secreting cells isolated from mouse stomach by fluorescence cell sorting (Zhao et al. 2010b). Subsequent to our study, Iwakura et al. (2011) examined the effects of 21 peptide hormones and 10 neurotransmitters on ghrelin secretion in a different ghrelinoma cell line, MGN3.1. Only three of the 31 compounds examined showed significant (i.e., greater than twofold) stimulation of ghrelin secretion: norepinephrine, epinephrine, and dopamine. These data confirm our findings with the exception of the dopamine result as discussed above. In this regard, neither our ghrelinoma cell lines (PG-1 and SG-1) nor our ghrelin-enriched gastric mucosal cells expressed any of the five dopamine receptor mRNAs, as measured by reverse transcription-polymerase chain reaction and microarray analysis.

The relevance of the in vitro findings to in vivo physiology was confirmed when we administered atenolol to fasted wild-type mice and found that it abolished the increase in plasma ghrelin that otherwise followed a 24-h fast. The increase was also abolished when we pretreated the mice with reserpine to deplete norepinephrine from sympathetic nerve endings (Zhao et al. 2010b).

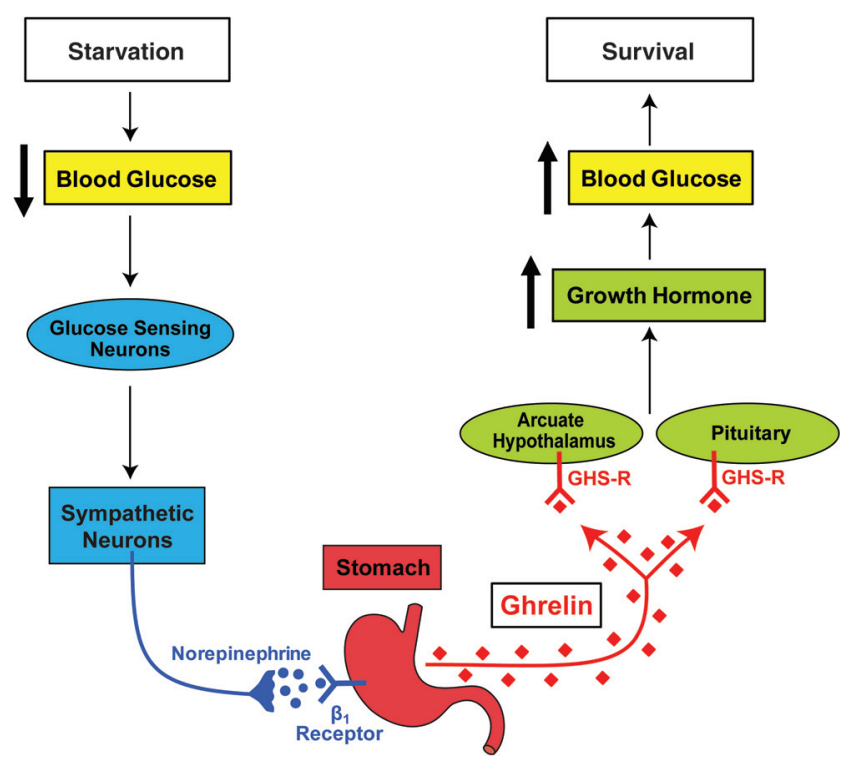

\section{MODEL ILLUSTRATING METABOLIC RESPONSE OF MICE TO PROLONGED STARVATION}

Figure 8 shows our current working model to integrate the findings so far. We propose that starvation tends to lower blood glucose, which is monitored by glucosesensing neurons somewhere in the central nervous system. This leads to activation of the sympathetic nervous system, which releases norepinephrine locally in the stomach wall, stimulating the secretion of ghrelin. Acting in the hypothalamus and pituitary, ghrelin stimulates secretion of growth hormone, which maintains blood glucose. This system is not essential to maintain blood glucose as long as adipose tissues are capable of releasing fatty acids. However, it becomes indispensable when adipose tissue stores have been severely depleted by chronic calorie depletion.

\section{Relevance to Anorexia Nervosa in Humans}

The relevance of the model in Figure 8 to human physiology remains to be demonstrated. For one thing, metabolism in humans is much slower than in the laboratory mouse, which normally consumes and burns food equal to $20 \%$ of its body weight per day. Humans would require much more than $7 \mathrm{~d}$ of calorie depletion in order to become severely deficient in adipose tissue. There is one clinical condition in which such depletion does occur, namely, in patients with anorexia nervosa. It is therefore intriguing that such patients have been demonstrated to maintain threefold elevations of plasma ghrelin and of growth hormone (Tanaka et al. 2004; Misra et al. 2005; Nass et al. 2011). We speculate that these elevations may be responsible for the maintenance of blood glucose in these adipose-deficient subjects. Despite these protective mechanisms, severe hypoglycemia is a serious
Figure 8. Model illustrating the metabolic response of wild-type mice to prolonged starvation. 
and rare fatal complication in anorexia nervosa patients when their body weight falls below $30 \mathrm{~kg}$ (Fonseca et al. 1991; Mattingly 1995; Yanai et al. 2008).

\section{ACKNOWLEDGMENTS}

This work was supported by a grant from the National Institutes of Health (HL20948). D.P.S. is the recipient of a postdoctoral fellowship from a Physician-Scientist Training Program at UT Southwestern Medical Center.

\section{REFERENCES}

Cahill GF Jr. 2006. Fuel metabolism in starvation. Annu Rev Nutr 26: 1-22.

Cummings DE, Purnell JQ, Frayo RS, Schmidova K, Wisse BE, Weigle DS. 2001. A preprandial rise in plasma ghrelin levels suggests a role in meal initiation in humans. Diabetes 50: 1714-1719.

Fonseca V, Ball S, Marks V, Havard CWH. 1991. Hypoglycaemia associated with anorexia nervosa. Postgrad Med J 67: $460-461$.

Gutierrez JA, Solenberg PJ, Perkins DR, Willency JA, Knierman MD, Jin Z, Witcher DR, Luo S, Onyia JE, Hale JE. 2008. Ghrelin octanoylation mediated by an orphan lipid transferase. Proc Natl Acad Sci 105: 6320-6325.

Hofmann K. 2000. A superfamily of membrane-bound $O$-acyltransferases with implications for Wnt signaling. TIBS 25: $111-112$.

Hosoda H, Kangawa K. 2008. The autonomic nervous system regulates gastric ghrelin secretion in rats. Regul Pept 146: $12-18$.

Iwakura H, Ariyasu H, Hosoda H, Yamada G, Hosoda K, Nakao K, Kangawa K, Akamizu T. 2011. Oxytocin and dopamine stimulate ghrelin secretion by the ghrelin-producing cell line, MGN3-1 in vitro. Endocrinol 152: 2619-2625.

Kamegai J, Tamura H, Shimizu T, Ishli S, Sugihara H, Wakabayashi I. 2001. Chronic central infusion of ghrelin increases hypothalamic neuropeptide $\mathrm{Y}$ and Agouti-related protein mRNA levels and body weight in rats. Diabetes 50: 2438-2443.

Kojima M, Kangawa K. 2005. Ghrelin: Structure and function. Physiol Rev 85: 495-522.

Kojima M, Hosoda H, Date Y, Nakazato M, Matsuo H, Kangawa K. 1999. Ghrelin is a growth-hormone-releasing acylated peptide from stomach. Nature 402: 656-660.

Mattingly DBS. 1995. Hypoglycaemia and anorexia nervosa. $J$ R Soc Med 88: 191-195.

Misra M, Miller KK, Kuo K, Griffin K, Stewart V, Hunter E, Herzog DB, Klibanski A. 2005. Secretory dynamics of ghrelin in adolescent girls with anorexia nervosa and healthy adolescents. Am J Physiol Endocrinol Metab 289: E347-E356.
Mundinger TO, Cummings DE, Taborsky GJ. 2006. Direct stimulation of ghrelin secretion by sympathetic nerves. Endocrinol 147: 2893-2901.

Nass R, Farhy LS, Liu J, Prudom CE, Johnson ML, Veldhuis P, Pezzoli SS, Oliveri MC, Gaylinn BD, Geysen HM, Thorner MO. 2008. Evidence for acyl-ghrelin modulation of growth hormone release in the fed state. J Clin Endocrinol Metab 93: $1988-1994$.

Nass R, Gaylinn BD, Thorner MO. 2011. The role of ghrelin in GH secretion and GH disorders. Mol Cell Endocrinol 340: $10-14$.

Sakata I, Yang J, Lee CE, Osborne-Lawrence S, Rovinsky SA, Elmquist JK, Zigman JM. 2009. Colocalization of ghrelin $O$-acyltransferase and ghrelin in gastric mucosal cells. Am J Physiol Endocrinol Metab 297: E134-E141.

Sun Y, Ahmed S, Smith RG. 2003. Deletion of ghrelin impairs neither growth nor appetite. Mol Cell Biol 23: 7973-7981.

Tanaka M, Nakahara T, Kojima S, Nakano T, Muranaga T, Nagai N, Ueno H, Nakazato M, Nozoe S, Naruo T. 2004. Effect of nutritional rehabilitation on circulating ghrelin and growth hormone levels in patients with anorexia nervosa. Regul Pept 122: 163-168.

Tschop M, Smiley DL, Heiman ML. 2000. Ghrelin induces adiposity in rodents. Nature 407: 908-913.

Wortley KE, Anderson KD, Garcia K, Murray JD, Malinova L, Liu R, Moncrieffe M, Thabet K, Cox HJ, Yancopoulos GD, et al. 2004. Genetic deletion of ghrelin does not decrease food intake but influences metabolic fuel preference. Proc Natl Acad Sci 101: 8227-8232.

Wren AM, Seal LJ, Cohen MA, Brynes AE, Frost GS, Murphy KG, Dhillo WS, Ghatei MA, Bloom SR. 2001. Ghrelin enhances appetite and increases food intake in humans. $J$ Clin Endoc Metab 86: 5992-5995.

Yanai H, Yoshida H, Tomono Y, Tada N. 2008. Severe hypoglycemia in a patient with anorexia nervosa. Eating Weight Disord 13: e1-e3.

Yang J, Brown MS, Liang G, Grishin NV, Goldstein JL. 2008a. Identification of the acyltransferase that octanoylates ghrelin, an appetite-stimulating peptide hormone. Cell 132: 387-396.

Yang J, Zhao T, Goldstein JL, Brown MS. 2008b. Inhibition of ghrelin $O$-acyltransferase (GOAT) by octanoylated pentapeptides. PNAS 105: 10750-10755.

Zhao T, Liang G, Li RL, Xie X, Sleeman MW, Murphy AJ, Valenzuela DM, Yancopoulos GD, Goldstein JL, Brown MS. 2010a. Ghrelin $O$-acyltransferase (GOAT) is essential for growth hormone-mediated survival of calorie-restricted mice. Proc Natl Acad Sci 107: 7467-7472.

Zhao T, Sakata I, Li RL, Liang G, Richardson JA, Brown MS, Goldstein JL, Zigman JM. 2010b. Ghrelin secretion stimulated by $\beta_{1}$-adrenergic receptors in cultured ghrelinoma cells and in fasted mice. Proc Natl Acad Sci 107: 15868-15873.

Zigman JM, Nakano Y, Coppari R, Balthasar N, Marcus JN, Lee CE, Jones JE, Deysher AE, Waxman AR, White RD, et al. 2005. Mice lacking ghrelin receptors resist the development of diet-induced obesity. $J$ Clin Invest 115: 3564-3572. 


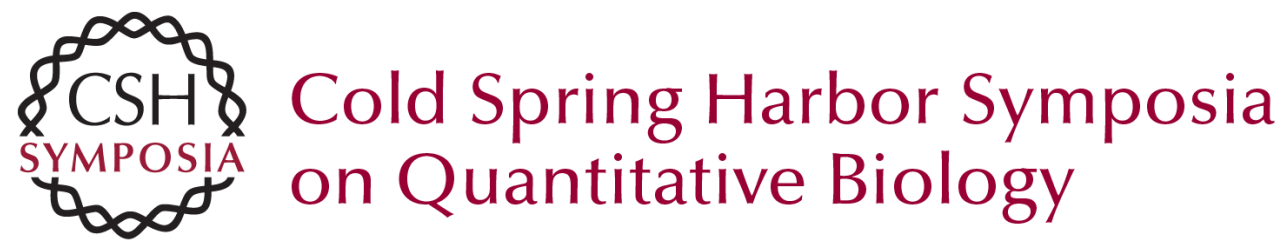

\section{Surviving Starvation: Essential Role of the Ghrelin-Growth Hormone Axis}

J.L. Goldstein, T.-j. Zhao, R.L. Li, et al.

Cold Spring Harb Symp Quant Biol 2011 76: 121-127 originally published online July 22, 2011 Access the most recent version at doi:10.1101/sqb.2011.76.010447

References This article cites 27 articles, 9 of which can be accessed free at: http://symposium.cshlp.org/content/76/121.full.html\#ref-list-1

License

Email Alerting Receive free email alerts when new articles cite this article - sign up in Service the box at the top right corner of the article or click here. 